\title{
Introduction to and Bibliography of Central European Women's Holocaust Life Writing in English
}

\author{
Louise O. Vasvári \\ State University of New York Stony Brook
}

Follow this and additional works at: https://docs.lib.purdue.edu/clcweb

Part of the Comparative Literature Commons, and the Critical and Cultural Studies Commons

Dedicated to the dissemination of scholarly and professional information, Purdue University Press selects, develops, and distributes quality resources in several key subject areas for which its parent university is famous, including business, technology, health, veterinary medicine, and other selected disciplines in the humanities and sciences.

CLCWeb: Comparative Literature and Culture, the peer-reviewed, full-text, and open-access learned journal in the humanities and social sciences, publishes new scholarship following tenets of the discipline of comparative literature and the field of cultural studies designated as "comparative cultural studies." Publications in the journal are indexed in the Annual Bibliography of English Language and Literature (Chadwyck-Healey), the Arts and Humanities Citation Index (Thomson Reuters ISI), the Humanities Index (Wilson), Humanities International Complete (EBSCO), the International Bibliography of the Modern Language Association of America, and Scopus (Elsevier). The journal is affiliated with the Purdue University Press monograph series of Books in Comparative Cultural Studies. Contact: <clcweb@purdue.edu>

\section{Recommended Citation}

Vasvári, Louise O. "Introduction to and Bibliography of Central European Women's Holocaust Life Writing in English." CLCWeb: Comparative Literature and Culture 11.1 (2009): <https://doi.org/10.7771/1481-4374.1422>

The above text, published by Purdue University Press @Purdue University, has been downloaded 3829 times as of $11 /$ $07 / 19$.

This document has been made available through Purdue e-Pubs, a service of the Purdue University Libraries. Please contact epubs@purdue.edu for additional information.

This is an Open Access journal. This means that it uses a funding model that does not charge readers or their institutions for access. Readers may freely read, download, copy, distribute, print, search, or link to the full texts of articles. This journal is covered under the CC BY-NC-ND license. 


\section{PURDUE}

UNIVERSITY PRESS <http://www.thepress.purdue.edu>

\section{CLCWeb: Comparative Literature and Culture}

ISSN 1481-4374 <http://docs.lib.purdue.edu/clcweb> Purdue University Press (C)Purdue University

CLCWeb: Comparative Literature and Culture, the peer-reviewed, full-text, and open-access learned journal in the humanities and social sciences, publishes new scholarship following tenets of the discipline of comparative literature and the field of cultural studies designated as "comparative cultural studies." In addition to the publication of articles, the journal publishes review articles of scholarly books and publishes research material in its Library Series. Publications in the journal are indexed in the Annual Bibliography of English Language and Literature (Chadwyck-Healey), the Arts and Humanities Citation Index (Thomson Reuters ISI), the Humanities Index (Wilson), Humanities International Complete (EBSCO), the International Bibliography of the Modern Language Association of America, and Scopus (Elsevier). The journal is affiliated with the Purdue University Press monograph series of Books in Comparative Cultural Studies. Contact: <clcweb@purdue.edu>

\section{Volume 11 Issue 1 (March 2009) Bibliography 10 Louise O. Vasvári, \\ "Introduction to and Bibliography of Central European Women's Holocaust Life Writing in English" <http://docs.lib.purdue.edu/clcweb/vol11/iss1/10>}

Contents of CLCWeb: Comparative Literature and Culture 11.1 (2009)

<http://docs.lib.purdue.edu/clcweb/vol11/iss1/>

Thematic Issue New Work in Holocaust Studies

Edited by Louise 0 . Vasvári and Steven Tötösy de Zepetnek

Abstract: In her "Introduction to and Bibliography of Central European Women's Holocaust Life Writing in English," Louise O. Vasvári discusses aspects and perspectives of women's life writing, including her criteria of selection, the problematics of sourcing, issues of translation, and processes of publication. While the authors listed in the bibliography are overwhelmingly Jewish and from Central and East Europe, there are works listed by others whose experiences also offer important testimony not only on the camps but also on other aspects of the Holocaust. The bibliography suggests that women have written as much and, especially during the last decades, more than men about the Holocaust. Vasvári postulates that life writing -- a term utilized mostly in gender studies but useful for other types of texts -- is a useful designation for the texts at hand because it elides generic boundaries between history, fiction, documentary, and literature. nota bene: for an updated version of this bibliography see CLCWeb: Comparative Literature and Culture (Library) (2012-): <http://docs.lib.purdue.edu/clcweblibrary/vasvariceushoahbib>. 
Louise O. Vasvári,

"Introduction to and Bibliography of Central European Women's Holocaust Life Writing in English" page 2 of 18

CLCWeb: Comparative Literature and Culture 11.1 (2009): <http://docs.lib.purdue.edu/clcweb/vol11/iss1/10>

Thematic Issue New Work in Holocaust Studies. Ed. Louise O. Vasvári and Steven Tötösy de Zepetnek

\section{Louise O. VASVÁRI}

\section{Introduction to and Bibliography of Central European Women's Holocaust Life Writing in English}

Although the emergence of research on women in the Holocaust dates from the 1980s, the task of integrating the role of women -- and that of children -- into Holocaust Studies is far from complete, not the least because of the publication of so many women's life writing texts during the last decades, most of which remain virtually unknown. Holocaust scholarship still tends to privilege the Holocaust experience of men as universal and is reluctant to acknowledge testimony that does not follow preconceived gender stereotypes of suitable female behavior or pre-existing narratives of survival (see, e.g., Vasvári, "Women's Holocaust"; Waxman, "Unheard Testimony"; authors of texts of life writing in English are listed in the bibliography; other references in this introduction are listed in the works cited). How many people are aware, for example, that the very first civilian transport to Auschwitz was not of men but of female "volunteers"? For example, in Rena Kornreich Gelissen's (a book written with Heather Dunn MacAdam) Rena's Promise: A Story of Sisters in Auschwitz, Gelissen writes how at age seventeen, imagining mistakenly she would be protecting her family, she volunteered for a work brigade in Auschwitz.

As part of my larger project for the retrieval and incorporation into Holocaust scholarship of women's voices like that of Gelissen, the bibliography contains about 400 entries of women's life writing about the Holocaust written in English or available in English translation (see also my companion article in this volume, "Emigrée"; see also Biró). The majority of the texts listed in the bibliography are by authors originally from Central and Eastern Europe proper. However, based on the proposition that Holocaust scholarship altogether ought to be conducted in the context of the region and its cultures (on this, see Tötösy de Zepetnek and Vasvári, "Introduction" in this volume), texts by authors from Western Europe are also included for the obvious reason that in the camps all, from East and West, suffered and perished together, and even many of those who survived in hiding in places in Western Europe, such as Holland or France, were often first- or second-generation Central European Jewish women, in many cases without citizenship in the country of their residence even if they had already been born in a Western European country (note the examples of two French-language memoirs by women born in France, Claudine Burinovic-Herbomel, whose parents were Romanian Jews, and Ida Grinspan Bertrand, born to Polish parents).

It is in English that most Holocaust life writing has been written and published because so many survivors ended up in emigration in English-speaking countries; in addition, most scholarly work on the Holocaust has appeared in English (with scholarship in German a distant second: I list only selected items of such in the bibliography whether primary texts or scholarship), so that English has turned out to be the lingua franca of Holocaust Studies. For this reason in the bibliography a translator or translated edition may be indicated but without data about the original text. This lack of data in the bibliography is explained by a problem in bibliography work in Holocaust Studies as discussed by Bella Brodzki: for example, after reading Claude Morhange-Begué's memoir in English, Brodzki tried to locate the French original without success and when she tracked down the translator, she learned that an original had never been published. And this is more frequently the case when originals were written in languages of Central Europe, including Yiddish. The problem of the source text is complicated further when a text is published first in English and is later translated and published in the "original" language, as in the case, for example, of Ita Dimant's A Diary of the Holocaust, first published in English in 1993, followed by its translated version published in Polish in 2001. Most striking is the case of Mary Berg's Warsaw ghetto diary, written in Polish, and first published in Yiddish and then English in 1945, and not until the mid-eighties in Polish. The relative lack of Holocaust texts published in Central and Eastern Europe proper, including scholarship, is because in postwar communist countries, anti- 
Louise O. Vasvári,

"Introduction to and Bibliography of Central European Women's Holocaust Life Writing in English" page 3 of 18

CLCWeb: Comparative Literature and Culture 11.1 (2009): <http://docs.lib.purdue.edu/clcweb/vol11/iss1/10>

Thematic Issue New Work in Holocaust Studies. Ed. Louise O. Vasvári and Steven Tötösy de Zepetnek

Semitism continues today (see Marsovszky; Pető; Tötösy de Zepetnek, "Imre Kertész") and because under Communism the Holocaust was a taboo subject except in the context of the fight against fascism (see Kisantal). And the problematics of women's Holocaust life writing is also fraught with matters such as the situation in Israel where survivors' texts and scholarship about them were perceived for a time as a threat to the masculinized nation-building discourse of Zionism (see Bos; Vasvári, "Women's Holocaust"; Zertal) or the situation in Latin America where large numbers of survivors emigrated, yet there is no published corpus of such life writing, with only an occasional second-generation son or daughter writing in the US of their parents' experiences (see, e.g., Agosín; Spitzer). Some few memoirs of note have appeared recently, such as Eva Eisenstaedt's story of how she survived Aushwitz, only to end up becoming one of the the "Plaza de Mayo" mothers in Argentina (see also Isacovici, Hazan, Wapner-Levin). There are many other memoirs, however, which mention brief interludes spent in Latin American countries before further emigration to more hospitable places (to cite only two examples, see Prager on how she reached Australia via Uruguay and Chile, or Jacoby on her and her mother's life in Havana before emigrating to the U.S.)

While the authors in this bibliography are overwhelmingly Jewish, there are works listed by others whose experiences also offer important testimony not only on the camps but other aspects of the Holocaust. Texts by gentiles in the bibliography include Genéviève de Gaulle (niece of Charles de Gaulle), Nanda Herberman, a Protestant in the women's camp of Ravensbrück, who wrote one of the very first camp memoirs, and Charlotte Delbo, with her unusual collective [auto]biography in the first person of about 230 women in her convoy, as well as others in the French Resistance such as by Lucie Aubrac, Claire Chevrillon, Christine Zamoyska-Panek, and Simone Arnold Liebster. Rescuers include Alicia Appellman-Jurman, Irene Gut Opolyke, and Corrie Ten Boon, while some gentiles might better be described as onlookers (e.g., Anonymous; Arnothy; Polcz; White; Zassenhaus). As the example of Krystyna Zywulska (Zosia Landau) illustrates, categories can be tenuous. In her I Survived Auschwitz, she wrote about being in Auschwitz as a political prisoner, which was true, but only twenty years later did she reveal to readers in her Pusta Woda (Empty Water) that she was a Jew who had walked out of the Warsaw ghetto in 1941 and worked as a gentile who was arrested and imprisoned as a resistance fighter. Zywulska's belated revelation at one point caused her memoir to be withdrawn from some Jewish institutions, a situation Elizabeth Baer argues against by pointing out that the question is not who is or is not a victim, or what is and what is not a Holocaust memoir, but "whether or not the memoir can contribute to that project of understanding" (22).

While I do not list in the bibliography collections of survivors' oral testimony such as those by Cynthia Crane, Jehoshua Eibeshitz and Anna Eibeshitz, Brana Gurewitsch, Vera Laska, Ilana Rosen, and Lore Shelley, such texts are, nevertheless, important with regard to the relevance of "ordinary" women who have not written themselves. Further, although I list items of texts by survivors and nonsurvivors, I emphasize the term "survivor" because of the larger corpus of writing by survivors. It is, therefore, important to remember that in spite of this, by far the two best-known female Holocaust voices -- Anne Frank and the Hungarian-born Hannah Senesh -- obviously do not fall into this category. While Anne Frank is known world-wide, Senesh is known only in Israel, where she has been promoted to heroic status as the Israeli Joan of Arc, precisely for her "nonfeminine" heroic traits (see Vasvári, "Women's Holocaust"; neither wrote about the camps and neither survived: it appears that for women survivors death is a necessary qualification for canonization, and the voices of these two women were until a decade ago available only in censored editions).

The posthumous works of other women Holocaust writers whom I list and who did not survive also merit consideration, including Etty Hillesum, Charlotte Salomon, and Irène Nemirovsky. It is interesting to compare Anne Frank with other teenage diarists who also did not survive, such as Hungarian Éva Heyman, who like Anne, began her diary on her thirteenth birthday and likely perished in Auschwitz at exactly the same time, or Ruthka Lieblich, who died in 1943 and whose diary was published in 
Louise O. Vasvári,

"Introduction to and Bibliography of Central European Women's Holocaust Life Writing in English" page 4 of 18

CLCWeb: Comparative Literature and Culture 11.1 (2009): <http://docs.lib.purdue.edu/clcweb/vol11/iss1/10>

Thematic Issue New Work in Holocaust Studies. Ed. Louise O. Vasvári and Steven Tötösy de Zepetnek

English only in 1993. There are also teenage diarists who survived, like Mary Berg, who published her diary of the Warsaw Ghetto in 1945 (earlier than Ann Frank's text) and Janina Bauman, who wrote her memoir only forty years later, partially based on the diary she had written in the Warsaw ghetto and hid under floorboards, as well as the Yiddish diaries of Vlada Meed and Lena Jedwab Rozenberg. Texts by survivors are still appearing over sixty years after the Holocaust, such as Hungarian survivor Erika Gottlieb's memoir, published only months after her death in 2008, as well as Edith Meyer Cord's 2008 story of her survival as a hidden child. More surprisingly, even diaries and letters from nonsurvivors are still surfacing at this late date, such as Ruthka Laskier's diary, who died at fourteen but whose diary was kept for sixty-three years by a girlfriend and published in 2007, and Hélène Berr's diary published in English in 2008.

Previous bibliographies on women's Holocaust texts are either outdated, owing to the increase of such texts since the 1990s, or they are limited. For example, the bibliography by Terence des Pres is now over thirty years old, while more recent ones, such as ones by Nehama Tec and Gisela Bock, list sixty-eight and about ninety entries, respectively, the latter including both men and women, with a predominance of German-language texts. While S. Lillian Kramer's, Esther Goldberg and Martin Gilbert's, and Alan Riggs's reference guides are useful for detailed entries on already well-known Holocaust writers, other bibliographies demote certain works by women into a separate category appropriate for "young adult" readers (e.g., Auerbach; Bitton-Jackson; Boraks-Nemetz; Ornstein; Richman; Roth-Hano; Soumerai). Some texts were written for such an audience -- as all those under the Puffin imprint -- but, as in the case of Isabelle Leitner's memoir rewritten for a younger readership, the borderlines are often nebulous. Interestingly, it is precisely those which are marketed to young readers that have stayed in print, such as prize winners for juvenile nonfiction, including Aranka Siegal's and Isabella Leitner's texts.

Most of the publications right after liberation were camp testimonies and some bibliographies have privileged these, sometimes rejecting those that did not devote "enough" space to that experience. However, more and more survivors who were not in camps but survived in hiding, in particular child survivors, including those who left on the Kindertransport, began to add their voices to the growing number of texts in life writing. Thus the steadily wider scope of writing has broadened the sense of the enormous dimensions of the Holocaust. In addition, with the largest number of survivors writing as late as half a century or more after their ordeal, equally relevant is how their Holocaust experience has marked their subsequent lives as survivors, and conversely, how their later -- often inter- and multilingual -- life has marked their memory of the Holocaust and their ways of narration (on the problematics of multilingualism, emotions, and the creating of new identity narratives in a new language, see Trahan; Polenko, Alan Rosen). These are issues I cannot discuss here, but as the single best memoir that addresses all these issues and does so from a feminist perspective, I recommend Ruth Klüger's Still Alive, an English-language recasting of her German-language text written a decade earlier (see Schaumann; Bos).

This bibliography suggests that women have written as much, and, especially during the last two decades or so, have written and published in fact more about the Holocaust than have men. It also shows how Holocaust testimonial writing began with liberation, with women's life writing always forming an important part: on this, see Zoë Waxman's Writing the Holocaust, who argues against the myth that survivors have come to tell stories only recently and discusses how gender affected how they narrate their stories. Note, for example, the following early works (as indicated, I list only those available in English), some based on diary material written during the war, all written in the first period between 1945-48, a few of which where published 1945-48, but many not until decades later. Today, with the possible exception of gentile Charlotte Delbo and perhaps Liana Millu, virtually none are known: Lucie Adelsberger, Seweryna Samaglewska, Mary Berg, Blanca Rosenberg, Pelagia Lewinska, Nanda Herberman, Sima Vaisman, Olga Lengyel, Ella Lingens-Reiner, Corrie Ten Boon, Gusta Da- 
Louise O. Vasvári,

"Introduction to and Bibliography of Central European Women's Holocaust Life Writing in English" page 5 of 18

CLCWeb: Comparative Literature and Culture 11.1 (2009): <http://docs.lib.purdue.edu/clcweb/vol11/iss1/10>

Thematic Issue New Work in Holocaust Studies. Ed. Louise O. Vasvári and Steven Tötösy de Zepetnek

vidson-Draenger, Liana Millu, Helen Warren, Juliana Tedeschi, Gisella Perl, Vladka Meed, and Krystyna Zywulska. Some of the earliest authors tended to be those who had special positions in the camps or were privileged in some other way, including some of the gentile prisoners or doctors and medical personnel such as Gisella Perl, the head gynocologist at Auschwitz, one of her assistants, Olga Lengyel (on Perl and Lengyel, see Vasvári, "Emigrée"), Sima Vaisman, and Lucie Adelsberger. On the other hand, as already noted, teenage diarists were also well represented. These first texts are particularly important because they were still written under the influence of the initial trauma and not yet influenced by other memoirs, testimonies, or scholarship. The testimony of Sima Vaisman illustrates particularly well many of these problems, and how, as I have pointed out, the lives and testimonies of Central and Eastern and Western European survivors are intertwined. Vaisman was born in Bessarabia (now Moldova) and received her medical degree in Bucharest, but, fleeing the increasing persecution of Jews in Romania, she moved to Paris, where she could only work as a dental surgeon. She was deported in January 1944 to Auschwitz-Birkenau, where she was relatively protected as she was assigned to the "hospital." Immediately upon her return she wrote for fear of losing precise memory. Her testimony, one of the earliest and the first written by a female doctor, was published in French as Le Monde juif in 1945. It was subsequently ignored, including by her, until a niece found it in a drawer in 1983; it was republished in the same journal in 1990, appeared as a small book in French in 1992, and in English translation in 2005.

As mentioned above, many other survivors had diaries or wrote recollections right after liberation but only published full works much later, for example, Isabelle Leitner, Rivka Leah Klein, and Judith Magyar Isaacson. Often details of precise dates, translators, and the like are impossible to trace for these earlier works. One illustration suffices: teenager Ana Novac managed to keep a diary in Hungarian on scraps she and her friend hid in their shoes in Auschwitz (see Vasvári, "Emigrée"). Although she became a successful writer, her diary was unpublishable in communist Romania after the war, a standard situation in communist countries, as I have noted. After she fled to Germany, it was published, surprisingly, in Hungarian (under her original name, Zimra Harsányi) in 1966, and the following year in German, but it is unclear if by herself. The subsequent year she emigrated to France, where the work appeared in her own translation. When, almost twenty-years later, there was interest in translating her work to English, she was dissatisfied with the quality of her earlier version and retranslated the text, with the aid of a magnifying glass, to French from her original Hungarian notes. It was this new and expanded 1996 self-translation that provided the basis for the 1997 English version.

Holocaust life writing continued to be published in a slow but steady stream, but it was not until around 1990, in what has been called by Leigh Gilmore "the age of trauma memoir," which includes survivor discourse and narratives of recovery (128-29), that a boom in such works started. That boom has reached such proportions that a New York Times commentary on a recent Jewish book fair could report that "Holocaust memoirs vied for time with cookbooks and diet books" (Donadio 31). The overwhelming majority of Holocaust texts are written today by women survivors or by their daughters, reflecting what was always true but not adequately theorized, that women tend to be able to talk and write about traumatic events more easily (on trauma and women's writing, see Henke; see also Vasvári, "Women's Holocaust").

Although most of the texts in the bibliography would be called, conventionally, "memoirs" or at times "testimonies," more useful is the more inclusive "life writing," a genre designation that avoids what Sidonie Smith and Julia Watson call the "ideologically fraught category of autobiography ... [in which] masculinist ideology has often dictated formal and epistemological terms of the genre" (18). I postulate that life writing is a useful designation for the texts at hand because it raises questions about issues much debated in Holocaust scholarship, including authorship versus narrator, witness, history, memory, interpretation, fact versus fiction, culture, identity, the processes of publishing, canon versus social perspectives of literature, and so on, and hence the contextual analysis of texts called 
Louise O. Vasvári,

"Introduction to and Bibliography of Central European Women's Holocaust Life Writing in English" page 6 of 18

CLCWeb: Comparative Literature and Culture 11.1 (2009): <http://docs.lib.purdue.edu/clcweb/vol11/iss1/10>

Thematic Issue New Work in Holocaust Studies. Ed. Louise O. Vasvári and Steven Tötösy de Zepetnek

"life writing," following the tenets of comparative cultural studies, results in new insight and avoids the relegation or exclusion of relevant writing and authors (on the framework of comparative cultural studies consult Tötösy de Zepetnek, "From Comparative Literature"; for the framework's application in the study of Central and Eastern European cultures and literatures relevant here, see his "Comparative Cultural"). Life writing -- although a genre designation applied mostly in feminist and gender studies -- is useful for many other types of texts. Life writing elides and blends generic boundaries between history, fiction, documentary, and literature in general, including the novel, to encompass autobiography, oral testimony, diaries, letters, the autobiographical novel, and other textual forms and genres. Smith and Watson propose fifty-two sub-genres of life writing, of which apology, autofiction, memoir, prison narrative, serial autobiography, survivor narrative, trauma narrative, and witnessing are the most frequent forms utilized by women survivors. Of these the most problematic is the category of autofiction, to which, for example, Imre Kertész's work also belongs (see Vasvári, "Emigrée"; Vasvári and Tötösy de Zepetnek), as do a number of other works from the 1960s and 1970s such as Zdena Berg's Tell Me Another Morning: A Novel or the work of Ilona Karmel and Ida Fink (see Milner). Marlene Heinemann has studied six survivors in this category who published such texts between 1957 and 1980: Gerda Klein, Charlotte Delbo, Judith Strick Dribben, Fania Fénélon, and Livia Bitton-Jackson (on factual and fictional elements in testimonials, see Richardson). Although Holocaust autofiction is less prevalent today, an occasional work still foregrounds its problematic nature, as Edith Hoffman's Unfinished Tears: A Novel ... But not a Fiction suggests.

A further category of women's Holocaust texts is transgeneric life writing, such as Edith Bruck's oeuvre (see Vasvári, "Emigrée"), all of it circling back on her Holocaust experience, for which the term memoir would be much too confining, located as it is on the boundaries of literary memoir, oral testimony, epistolary works, prayer, all "recycled" to portray the Holocaust from a woman's perspective and highlight the role of gender in the creation of memory. Among other examples are Susan Suleiman's memoir, built around a diary written during her postcommunist visit to Hungary and Poland and called a "postmodern memoir" on the book's dust jacket by Kate Shulman; Lilian Boraks-Nemetz's poems drawing on her experience as a child survivor in the Warsaw ghetto; Irene Klepfisz's feminist essays drawing on a similar experience; and several epistolary works such as by Hilde Verdoner-Sluizer or Lotte Strauss (a memoir begun in 1975 as a letter to her daughter that took twenty years to complete). Consider also Felicia (Sleigman) Carmelly writing as a survivor of the little-known Transnistrian slaughter, combining in her work scholarship, family memoir, and memorial, or Anette Kahn, whose father was executed by Klaus Barbie when she was two years old. As a courtroom journalist, Kahn covered the Barbie trial, producing a work combing courtroom drama, testimonies of survivors, accounts of Barbie's career, and accounts of her own and her parents' lives.

The term life writing also underlines the continuity of life and hence of survivor's stories after the war. Although many of the works listed here, even some written more recently, end with liberation, the majority understandably go on to recount life after. Contrast, for example, two Jewish-Italian survivors, Juliana Tedeschi, who limits her story strictly to her camp experience, ending it with liberation and not even letting the reader know the fate of her baby, left behind in hiding, and Liana Millu, who includes her postliberation psychological re-adaptation to freedom. Georgia Gabor devotes most of her book to her Holocaust experience and a following year of life in postwar Hungary, but includes a second part of sixty-seven pages on her new life in the US as a war orphan, which by her own testimony was psychologically even more devastating than her wartime near-death experiences. Only one-eighth of Evie Blakie's work is devoted directly to her Holocaust experience as a hidden child; the rest of her book describes her life feeling a perennially displaced person in four different cultures and not considering writing until she recognizes herself as a survivor at the first Hidden Children Conference in 1982. Similarly, Paula Marcus, a fifteen-year-old Hungarian survivor, started her first diary entry hours after liberation; three years later, by this time in the US, like Gabor, she felt isolated and bitter. When read- 
Louise O. Vasvári,

"Introduction to and Bibliography of Central European Women's Holocaust Life Writing in English" page 7 of 18

CLCWeb: Comparative Literature and Culture 11.1 (2009): <http://docs.lib.purdue.edu/clcweb/vol11/iss1/10>

Thematic Issue New Work in Holocaust Studies. Ed. Louise O. Vasvári and Steven Tötösy de Zepetnek

ing her diary thirty years later and translating it herself to English, she recalls how at age fifteen she found liberation life confirming, providing warmth, solidarity, and people who listened (see Greenspan 52-55).

A special case of life writing is two-voiced life writing, what Bella Brodzki referred to as the intergenerational and intercultural transmission of imperiled narratives, conceived as acts of translation, in and through a space of thick translation from orality to textuality. Brodzki studies the memoir by Morhange-Begué, originally written in French but published only in English translation, where the author describes how she and her mother survived. Since her mother cannot write her own story, it falls to the daughter to textualize the mother's narrative. Similarly, Susan Varga, whose mother had always said she was waiting for her daughter to write her story, tapes her mother's testimony, but constructs a story of both their lives, even as the wartime stories really belong to her mother, since she herself was an infant. Miriam Katin achieves something similar with the new form of "comix," akin to Art Spiegelman's work (see Vasvári, "Emigrée"). These authors all belong to the youngest members of the "1.5 generation" of child survivors with few or no independent memories of their own, thus, although in a physical sense they are survivors, their early stories have to be textualizations of their parental oral narratives.

In the bibliography I do not include the large corpus of so-called postmemory life writing by children of survivors, who started writing during the same boom of the early 1990s as their mothers and who are overwhelmingly women. I include, however, examples written by those second-generation daughters who are attempting to ventriloquize their parents' stories rather than, or in addition to, telling their own second-generation ones. Perhaps most notable are the sister pair, Elaine Kalman Naves and Judith Kalman, who each wrote the stories of each of their parents (on the Kalmans and other Central European women's texts in English, see Tötösy de Zepetnek, "English-language"; Vasvári, "Emigrée"in this volume). Ann Kirschner put together Sala's Gift about her mother's life from a cardboard box that contained letters her mother handed her when at age sixty-seven she was to undergo triple bypass surgery. The contents cleared up the life that the mother had until then been silent about, her large family who had perished in the Holocaust, her own wartime ordeal in 1940 when as teenager she volunteered (on behalf of her weaker older sister) to work in a Nazi labor camp, and the years up to 1946 when she arrived in New York as a war bride. The exceptional man in textualizing the maternal voice is Martin Lemelman (in French compare Jérôme Clément on his Russian-born mother's life), who in Mendel's Daughter taped the story of his mother, born in 1922 in a small Jewish village in Poland. In 1989, much like Spiegelman's father, she told her story to her son in fractured English combined with Yiddish (Lemelman claims for himself no more than the role of transcriber and editor of his mother's story; some of her story can be listened to at <http://www.mendelsdaughter.com/broadband.htm>).

Finally, life writing also elides the often value-laden and normative judgment of the literary merit of texts. Note the example of Ruth Klüger's work, initially rejected by the major German publishing house Suhrkamp on the grounds that it was not "literary" enough; in 1992, it appeared and met with enormous success, made its small publishing house Wallstein famous, garnered numerous literary awards, and was translated to several languages: never before had a Holocaust testimony been so successful in Germany (see Schaumann). At the other extreme is a memoir like that by Judith Jaegermann, whom Ilana Rosen would locate among the "so-called ordinary people" who normally participate, if at all, only in oral testimony or in communal memorial books (Sisters in Sorrow). In a slim fifty-seven pages, written in a simple style, an outcome of her attending courses in 1985 in Yad Vashem to learn to tell her story, Jaegermann talks about her prewar life as "perfect" and can say nothing substantially new. Yet her book contains poignant anecdotes that illustrate on a personal level the theoretical points I am discussing here about how so many survivors were silenced from speaking both in public and in private. In a chapter entitled somewhat ironically, "Free At Least!?" she tells how, 
Louise O. Vasvári,

"Introduction to and Bibliography of Central European Women's Holocaust Life Writing in English" page 8 of 18

CLCWeb: Comparative Literature and Culture 11.1 (2009): <http://docs.lib.purdue.edu/clcweb/vol11/iss1/10>

Thematic Issue New Work in Holocaust Studies. Ed. Louise O. Vasvári and Steven Tötösy de Zepetnek

from Bergen-Belsen to Prague, her group stopped in Pilsen and people asked about their tattooed numbers; when she told them about three-and-a-half years in concentration camp, they replied: "And why didn't you stay where you were? Who needs you here?" (18). When, as the sole survivor of her family she finally reached Israel, her sister, who had lived there since 1939 and whom she had hoped would show her sympathy and comfort her, never once asked what she went through. Finally, when Eichmann went on trial in Israel in 1961, people suddenly started asking questions, but then "after the trial, nobody asked any more questions" (57). As Esther Goldberg writes in her Memoir Digest of Survivors, "each memoir writer has a different story to tell and tells his or her story in a different way ... every memoir is informative ... [and] poignant" ( $\mathrm{x}-\mathrm{xi})$ and as Alvin Rosenfeld writes in his A Double Dying, if we deny the centrality of Holocaust literature we would be falsifying not only the literary history of our time but also the moral history, a statement that becomes all the more true if we do not include the voices of women as well as other hitherto underrepresented victims, Jewish, gentile, Roma, gay and lesbian, communist, Catholic, and so on.

\section{Works Cited}

Agosín, Marjorie. A Cross and a Star: Memoirs of a Jewish Girl in Chile. 1994. Trans. Celeste KostopulosCooperman. Albuquerque: $U$ of New Mexico P, 1995.

Baer, Elizabeth. "Complicating the Holocaust: Who is a Victim? What is a Holocaust Memoir?" Remembering the Future: The Holocaust in an Age of Genocide. Ed. John K. Roth and Elizabeth Maxwell. London: Palgrave, 2000. 15-23.

Biró, Ruth G. "Representations of Budapest 1944-1945 in Holocaust Literature." Comparative Central European Holocaust Studies. Ed. Louise O. Vasvári and Steven Tötösy de Zepetnek. West Lafayette: Purdue UP, 2009. 317.

Bock, Gisela, ed. Genozid und Geschlecht. Jüdische Frauen im nationalsozialistischen Lagersystem. Frankfurt: Campus, 2005.

Bos, Pascale. German-Jewish Literature in the Wake of the Holocaust: Greta Weil and Ruth Klüger and the Politics of Address. New York: Palgrave, 2005.

Brodzki, Bella. "Trauma Inherited: Trauma Reclaimed: Chambert, Recollections from an Ordinary Childhood." Yale Journal of Criticism 14.1(2001): 155-67.

Burinovico-Herbomel, Claudine. Une enfance traquée. Témoignage. Paris: Improvisto, 2001.

Clément, Jérôme. Plus tard, tu comprendras. Paris: Grasset, 2005.

Crane, Cynthia. Divided Lives: The Untold Stories of Jewish-Christian Women in Nazi Germany. New York: Palgrave McMillan, 2003.

Donadio, Rachel. "Star Search." New York Times Sunday Book Review (24 June 2007): 31.

De Pres, Terence. The Survivor: An Anatomy of Life in the Death Camps. New York: Oxford UP, 1976.

Eibeshitz, Jehoshua, and Anna Eibeshitz, ed. Women in the Holocaust: A Collection of Testimonies. New York: Remember, 1993.

Eisenstaedt, Eva. Sobrevivir dos veces; de Auschwitz a madre de Plaza de Mayo. Buenos Aires: Editorial Milà, 2007.

Gilmore, Leigh. "Limit-Cases: Trauma, Self-Representation and the Jurisdictions of Identity." Biography 24.1 (2001): 128-40.

Goldberg, Esther, and Martin Gilbert. Holocaust Memoir Digest: Survivors' Published Memoirs with Study Guide and Maps. Portland: Vallentine Mitchell, 2004.

Greenspan, Henry. "'An Immediate and Violent Impulse:' Holocaust Survivor Testimony in the First Years after Liberation." Remembering the Future: The Holocaust in an Age of Genocide. Ed. John K. Roth and Elizabeth Maxwell. London: Palgrave, 2000. 108-16.

Grinspan, Ida, and Bertrand Poirot-Delpech. J'Ai pas pleuré. Paris: Robert Laffont, 2002.

Gurewitsch, Brana, ed. Mothers, Sisters, Resisters: Oral Histories of Women Who Survived the Holocaust. Tuscaloosa: U of Alabama P, 1998.

Hazan, Martín. Un día más de vida: Rodas-Auschwitz-Buenos Aires. La odisea de David Galante. Buenos Aires: Lumière, 2007.

Heineman, Marlene E. Gender and Destiny: Women Writers and the Holocaust. Westport: Greenwood, 1982.

Henke, Suzette. Shattered Subjects: Trauma and Testimony in Women's Life Writing. New York: St. Martin's P, 2000.

Isacovici, Salomón. 1992. A7393, hombre de cenizas. Man of Ashes. Lincoln: University of Nebraska P, 1999.

Kisantal, Tamás. "The Holocaust as a Paradigm for Ethical Thinking and Representation." Comparative Central European Holocaust Studies. Ed. Louise O. Vasvári and Steven Tötösy de Zepetnek. West Lafayette: Purdue UP, 2009. 18-27.

Kramer, S. Lillian. Holocaust Literature: An Encyclopedia of Writers and Their Work. New York: Routledge, 2003. 
Louise O. Vasvári,

"Introduction to and Bibliography of Central European Women's Holocaust Life Writing in English" page 9 of 18

CLCWeb: Comparative Literature and Culture 11.1 (2009): <http://docs.lib.purdue.edu/clcweb/vol11/iss1/10>

Thematic Issue New Work in Holocaust Studies. Ed. Louise O. Vasvári and Steven Tötösy de Zepetnek

Laska, Vera. Women in the Resistance and in the Holocaust: The Voices of Eyewitnesses. Westport: Greenwood, 1983.

Lemelman, Martin. mendelsdaughter (2008): <http://www.mendelsdaughter.com/broadband.htm>.

Marsovszky, Magdalena. "About Antisemitism in Post-1989 Hungary." Comparative Central European Holocaust Studies. Ed. Louise O. Vasvári and Steven Tötösy de Zepetnek. West Lafayette: Purdue UP, 2009. 28-39.

Marsovszky, Magdalena. "Cultural Essentialism in Post-1989 Hungary." The New Central and East European Culture. Ed. Steven Tötösy de Zepetnek, Carmen Andraş, and Magdalena Marsovszky. Aachen: Shaker, 2006. 268-76.

Milner, Iris. "Towards a New Reading of Fink's The Journey." Comparative Central European Holocaust Studies. Ed. Louise O. Vasvári and Steven Tötösy de Zepetnek. West Lafayette: Purdue UP, 2009. 147-57.

Petö, Andrea. "About the Narratives of a Blood Libel Case in Post-Shoah Hungary." Comparative Central European Holocaust Studies. Ed. Louise O. Vasvári and Steven Tötösy de Zepetnek. West Lafayette: Purdue UP, 2009. 40-52.

Polenko, Aneta, ed. Emotions and Multilingualism. Clevendon: Multilingual Matters, 2006.

Richardson, Anna. "Mapping the Lines of Fact and Fiction in Holocaust Testimonial Novels." Comparative Central European Holocaust Studies. Ed. Louise O. Vasvári and Steven Tötösy de Zepetnek. West Lafayette: Purdue UP, 2009. 53-66.

Riggs, Thomas, ed. Reference Guide to Holocaust Literature. Detroit: St. James P, 2002.

Rosen, Ilana, ed. Hungarian Jewish Women Survivors Remember the Holocaust. Dallas: UP of America, 2004.

Rosen, Ilana. "Rescue Narratives and Conceptualizations by Holocaust Survivors from Carpatho-Russia." Comparative Central European Holocaust Studies. Ed. Louise O. Vasvári and Steven Tötösy de Zepetnek. West Lafayette: Purdue UP, 2009. 67-78.

Rosen, Ilana. Sisters in Sorrow: A Journey to the Life Histories of Female Holocaust Survivors from Hungary. Detroit: Wayne State UP, 2008.

Rosen, Alan. Sounds of Defiance: The Holocaust Multilinguals and the Problem of English. Lincoln: $\mathrm{U}$ of Nebraska P, 2005.

Rosenfeld, Alvin. A Double Dying: Reflections on Holocaust Literature. Bloomington: Indiana UP, 1980

Schaumann, Caroline. "From weiter leben (1992) to Still Alive (2001): Ruth Klüger's Cultural Translation of Her 'German Book' for an American Audience." The German Quarterly 77.3 (2004): 324-39.

Shelley, Lore. Auschwitz -- the Nazi Civilization: Twenty-Three Women Prisoners' Accounts. Lanham: UP of America, 1992.

Smith, Sidonie, and Julia Watson. Reading Autobiography: A Guide for Interpreting Life Narratives. Minneapolis: U of Minnesota P, 2001.

Spiegelman, Art. Maus: A Survivor's Tale. My Father Bleeds History. New York: Pantheon, 1982.

Spitzer, Leo. Hotel Bolivia: The Culture of Memory in a Refugee from Nazism. New York: Hill and Wang, 1998.

Suleiman Rubin, Susan. "The 1.5 Generation: Thinking about Child Survivors of the Holocaust." American Imago 59.3 (2002): 277-96.

Tec, Nehama. Resilience and Courage: Women, Men, and the Holocaust. New Haven: Yale UP, 2003.

Tötösy de Zepetnek, Steven. "Comparative Cultural Studies and the Study of Central European Culture." Comparative Central European Culture. Ed. Steven Tötösy de Zepetnek. West Lafayette: Purdue UP, 2002. 1-32.

Tötösy de Zepetnek, Steven. "From Comparative Literature Today toward Comparative Cultural Studies." Comparative Literature and Comparative Cultural Studies. Ed. Steven Tötösy de Zepetnek. West Lafayette: Purdue UP, 2003. 235-67.

Tötösy de Zepetnek, Steven. "English-Language Memoir Literature by Central European Jewish Women." Zions Töchter. Jüdische Frauen in Literatur, Kunst und Politik. Ed. Andrea M. Laurisch. Wien: LIT, 2006. 139-48.

Tötösy de Zepetnek, Steven. "Imre Kertész's Nobel Prize in Literature and the Print Media." Imre Kertész and Holocaust Literature. Ed. Louise O. Vasvári and Steven Tötösy de Zepetnek. West Lafayette: Purdue UP, 2005. 232-46.

Trahan, Elizabeth Welt. "Writing a Holocaust Memoir in Two Languages: A Balancing Act." Metamorphoses 8.2 (2000): 256-63.

Vasvári, Louise O. "The Novelness of Imre Kertész's Sorstalanság (Fatelessness)." Imre Kertész and Holocaust Literature. Ed. Louise O. Vasvári and Steven Tötösy de Zepetnek. West Lafayette: Purdue UP, 2005. $258-70$.

Vasvári, Louise O. "Women's Holocaust Memories: Trauma, Testimony and the Gendered Imagination." Jewish Studies. Ed. András Kovács and Michael I. Miller. Budapest: Central European UP, 2006-07. 141-56.

Vasvári, Louise O. "Emigrée Central European Jewish Women's Holocaust Life Writing." CLCWeb: Comparative Literature and Culture 11.1 (2009): <http://docs.lib.purdue.edu/clcweb/vol11/iss1/7>.

Vasvári, Louise O., and Steven Tötösy de Zepetnek, eds. Imre Kertész and Holocaust Literature. West Lafayette: Purdue UP, 2005.

Waxman, Zoë. "Unheard Testimony, Untold Stories: The Representation of Women's Holocaust Experiences." Women's History Review 12.4 (2003): 661-77.

Wapner-Levin, Paje. Von Vilna nach Buenos Aires. Erinnerungen einer Lehrerin an den Holocaust. Bremen: Donat, 2006.

Waxman, Zoë. Writing the Holocaust: Identity, Testimony, Representation. Oxford: Oxford UP, 2006.

Zertal, Ideth. Israel's Holocaust and the Politics of Nationhood. Trans. Chaya Galai. Cambridge: Cambridge UP, 2005. 
Louise O. Vasvári,

"Introduction to and Bibliography of Central European Women's Holocaust Life Writing in English" page 10 of 18

CLCWeb: Comparative Literature and Culture 11.1 (2009): <http://docs.lib.purdue.edu/clcweb/vol11/iss1/10>

Thematic Issue New Work in Holocaust Studies. Ed. Louise O. Vasvári and Steven Tötösy de Zepetnek

\section{Bibliography of Central European Women's Holocaust Life Writing in English}

Aaron, Frieda W. Bearing the Unbearable. Albany: State U of New York P, 1990.

Abramovitch, Maja. To Forgive ... But not to Forget: Maja's Story. London: Library of Holocaust Testimony, 2002.

Adelsberger, Lucie. Auschwitz: A Doctor's Story. 1953. Trans. Susan Ray. Boston: Northeastern UP, 1995.

Adler, Alice Dunn. Boriska's Prophecy: A True Story of Survival and Renewal. Never Told Before: An Autobiography. Reston: Acropolis Books, 1991.

Akavia, Miriam. An End to Childhood. 1975. Trans. Michael P. McCleary and Jeanette Goldman. London: Vallentine Mitchell, 2001.

Akavia, Miriam. My Vineyard: A Jewish Family in Krakow between the Wars. 1977. Trans. Richard Flanz and Rafael F. Scharft. London: Vallentine Mitchell, 1995.

Alexander, Caroline. Now You Are Sara. Brentwood Bay: Ben-Simon Publications, 1993.

Alland, Brnislawa. Memoirs of a Hidden Child During the Holocaust. Lewiston: Edwin Mellen, 1992.

Altbeker, Cyprys, Ruth. A Jump for Life: A Survivor's Journal from Nazi-Occupied Poland. New York: Continuum, 1997.

Amariglio, Erika Kounio. From Thessaloniki to Auschwitz and Back. Trans. Theresa Sundt. Portland: Vallentine Mitchell, 2000.

Anonymous. A Woman in Berlin: Eight Weeks in the Conquered City. A Diary. 2000. Trans. Philip Boem. New York: Henry Holt, 2005.

Appellman-Jurman, Alicia. Alicia: My Story. Survival and Heroism of a Young Girl during the Holocaust. New York: Bantam, 1988.

Arnothy, Christine. I Am Fifteen and I Don't Want to Die. Trans. Antonia White. New York: Scholastic, 1956.

Arnstein, Lenke.. Recurring Dreams. Caulfield South: Makor Jewish Community Library, 2002.

Aschkenasy, Nehama. Eve's Journey. Philadelphia: U of Pennsylvania P, 1986.

Aubrac, Lucie. Outwitting the Gestapo. 1945. Trans. Konrad Bieber and Betsy Wing. Lincoln: U of Nebraska P, 1992.

Auerbacher, Inge. I Am a Star: Child of the Holocaust. London: Puffin, 1993.

Bacall-Zwirn, Alina, and Jared Stark. No Common Place: The Holocaust Testimony of Alina Bacall-Zwirn. Lincoln: U of Nebraska P, 1999.

Bacon, Ursula. Shanghai Diary: A Young Girl's Journey from Hitler's Hate to War-Torn China. Milwaukie: M P, 2004.

Bacon, Ursula. Eternal Strangers. Milwaukie: M P, 2007.

Balsam, Eda Lew. Escape from Antwerp: From Terror to Paradise. Santa Cruz: E.L. Balsam, 2003.

Banat, Chana Marcus. They Called Me Frau Anna. New York: CSI, 1991.

Barac, Barbara. Escape from Destiny: Holocaust Memoires from the Ukraine. Melbourne: Jewish Holocaust Resource Centre, 1990.

Barak-Ressler, Alyza. Cry Little Girl: A Tale of the Survival of a Family in Slovakia. Jerusalem: Yad Vashem, 2003.

Bas-Meltzer, Esther. In the Claws of Destruction. 1950. Toronto: Aron Horowitz Publications, 1986.

Bauman, Janina. Beyond these Walls: Escaping the Warsaw Ghetto. A Young Girl's Story. London: Virago, 1986.

Bell, Susan Grog. Between Worlds: In Czechoslovakia, England, and America. New York: Dutton, 1991.

Benish, Pearl. To Vanquish the Dragon. New York: Feldman Publishers, 1991.

Berg, Mary. The Diary of Mary Berg: Growing Up in the Warsaw Ghetto. New York: One World Publications, 1945.

Berger, Zdena. Tell Me Another Morning: A Novel. New York: Harper, 1961.

Bergman, Paulina. And Not as a Broken Shard. 1987. Tel Aviv: By the Author, 2007.

Berkowitz, Sarah Bick. Where are My Brothers? From the Ghetto to the Gas Chamber. New York: Helios, 1965.

Berkowitz, Sarah Bick. In Search of Ashes. New York: Shengold, 1984.

Berland-Hyatt, Felicia. Close Call: Memoirs of a Survivor. New York: Holocaust Library, 1991.

Bernstein, Sarah Tuvel. The Seamstress. New York: Putnam, 1997.

Berr, Hélène. The Journal of Helene Berr. Trans. David Bellow. Toronto: M \& S, 2008.

Bielenberg, Christabel. When I was German, 1934-1945: An Englishwoman in Nazi Germany. Lincoln: U of Nebraska $\mathrm{P}, 1998$.

Bikales, Gerda. Through the Valley of the Shadow of Death. New York: iUniverse, 2004.

Birenbaum, Halina. Hope is the Last to Die. 1967. Trans. David Welsh. Armonk: Sharpe, 1996.

Birger, Trudi, with Jeffrey M. Green. A Daughter's Gift of Love: A Holocaust Memoir. Philadelphia: The Jewish Publication Society, 1992.

Birnak, Alice. Next Year, God Willing. New York: Shengold, 1994.

Bitton-Jackson, Livia. Elli: Coming of Age in the Holocaust. 1984. London: Simon and Schuster, 1999.

Bitton-Jackson, Livia. I Have Lived a Thousand Years: Growing Up in the Holocaust. New York: Simon and Schuster, 1997.

Blaikie, Evi. Magda's Daughter: A Hidden Child's Journey Home. New York: Feminist Press of the City $U$ of New York, 2002.

Blau, Magda. From Childhood to Auschwitz. Melbourne: By the Author, 2003.

Bleier, Inge Joseph, and David E. Gumpert. Inge: A Girl's Journey through Nazi Germany. New York: Eerdmans, 2004.

Blend, Martha. A Child Alone. London: Vallentine Mitchell, 1995. 
Louise O. Vasvári,

"Introduction to and Bibliography of Central European Women's Holocaust Life Writing in English" page 11 of 18

CLCWeb: Comparative Literature and Culture 11.1 (2009): <http://docs.lib.purdue.edu/clcweb/vol11/iss1/10>

Thematic Issue New Work in Holocaust Studies. Ed. Louise O. Vasvári and Steven Tötösy de Zepetnek

Blumenstein, Lili Wider. Lili. New York: Shengold, 1990.

Blumstein, Rita Blattberg. Like Leaves in the Wind. London: N and M, 2003.

Bodnar, Piri Piroska. Shadows: The Legacy of a Holocaust Survivor. Santa Barbara: Fithian P, 1998.

Boraks-Nemetz, Lillian. The Old Brown Suitcase: A Teenager's Story of War and Peace. Brentwood Bay: Berr Simon, 1995.

Boraks-Nemetz, Lilian. Ghost Children: Poems. Vancouver: Ronsdale P, 2000.

Bradfeld, Susi. But Some Became Stars. Jerusalem: Gefen, 1998.

Brand, Sandra. I Dared to Live. New York: Shengold, 1978.

Brand, Sandra. Between Two Worlds. New York: Shengold, 1982.

Brand, Sandra. Roma During Two Invasions. New York: Shengold, 1992.

Brewda, Alina. I Shall Fear No Evil. London: Kimber, 1966.

Brewster, Eva. Progeny of Light: Vanished in Darkness. Edmonton: NeWest P, 1984.

Bruck, Edith. Who Loves You Like This. 1957. Trans. Thomas Kelso. Philadelphia: Paul Dry Book, 2000.

Bruck, Edith. Letter to My Mother. 1988. Trans. Brenda Webster and Gabriella Romani. New York: Modern Language Association of America, 2006.

Bruell, Anna. Autumn in Springtime. Melbourne: Bruell, 1995.

Buber-Neumann, Margarete. Under Two Dictators. 1949. Trans. Edward Fitzgerald. New York: Dodd Mead, 1999.

Buchwalter, Marianne. Memories of a Berlin Childhood. Corvalis: Oregon Council for the Humanities, 1995.

Cassab, Judith. Diaries. Sydney: Alfred Knopf, 1995.

Censor, Maria. Letters to My Mother. Melbourne: Makor Jewish Community Library, 2000.

Chayen, Lea Fuchs. From the Depths I Call. Southfield: Targum, 2000.

Chevrillon, Claire. Code Name Christianne Clouet: A Woman in the French Resistance. Trans. Jane Kielty Stott. College Station: Texas A\&M UP, 1995.

Chirurg, Riva. Bridge of Hope, Bridge of Sorrow. Berkeley: Judah L. Magnes Museum, 1994.

Christophe, Francine. From a World Apart: A Little Girl in the Concentration Camps. Lincoln: U of Nebraska P, 2000.

Cord, Edith Meyer. Becoming Edith: The Education of a Hidden Child. Whitmore Lake: Wordsmith, 2008

Cretzmeyer, Stacy. Your Name is Renee: Ruth Kapp Hartz's Story as a Hidden Child in Nazi-Occupied France. Oxford: Oxford UP, 1999.

Cukierman, Doba-Necha. A Guardian Angel: Memories of Lubin. Melbourne: E. Csaky, 1997.

Cyprys, Ruth Albeker. A Jump for Life: A Survivor's Journal from Nazi-Occupied Poland. New York: Continuum, 1999.

Czeigler Visontay, Rose. Boutique. 1976. Trans. Joseph Daniel. Sydney: New Life Printery, 1976.

David, Janina. A Square of Sky. London: Hutchison, 1964.

David, Janina. A Touch of Earth. London: Hutchison, 1966.

David, Janina. Memoirs of a Wartime Childhood. London: Eland, 1992.

David, Ruth L. Child of Our Time: A Young Girl's Flight from the Holocaust. New York: I.B. Tauris, 2003.

Davidson-Draenger, Gusta. Justyna's Narrative. 1946. Ed. Eli Pfefferkorn and David H. Hirsch. Trans. Roslyn Hirsch. Amherst: $U$ of Massachusetts P, 1995.

Davidowitz, Lucy. From that Place and Time: A Memoir, 1938-1947. New York: Norton, 1989.

Davis, Ellen. Kerry's Children: A Jewish Childhood in Nazi Germany and Growing up in South Wales. Bridgeend: Seren, 2004.

De Gaulle-Anthonioz, Genéviève. The Dawn of Hope: A Memoir of Ravensbrück. Trans. Richard Sever. New York: Arcade, 1999.

Delbo, Charlotte. Auschwitz and After. 1946. Trans. Rosette C. Lamont. New Haven: Yale UP, 1995.

Delbo, Charlotte. Days and Memory. 1985. Trans. Rosette Lamont. Marlboro: The Marlboro P, 1999.

Delbo, Charlotte. Convoy to Auschwitz: Women of the French Resistance. 1978. Trans. Carol Cosman. Boston: Northeastern UP, 1997.

Delbo, Charlotte. None of Us Will Return. 1965. Trans. John Githens. Boston: Beacon P, 1968.

Demetz, Hanna. The House on Prague Street. 1970. New York: W.H. Allen, 1980.

Demetz, Hanna. The Journey from Prague Street. 1978. New York: St. Martin's, 1990.

Denes, Magda. Castles Burning: A Child's Life in War. New York: Norton, 1997.

Deutsch, Mina. Mina's Story: A Doctor's Memoir of the Holocaust. Toronto: ECW, 1994.

Deutschkron, Inge. Outcast: A Jewish Girl in Wartime Berlin. 1976. Trans. Jean Steinberg. New York: Fromm International Publishing, 1989.

Dimant, Ita. A Diary of the Holocaust. Brooklyn: By the Author, 1993.

Dribben, Judith Strick. And Some Shall Live. Jerusalem: Keter Books, 1969.

Dribben, Judith Strick. A Girl Called Judith Strick. New York: Cowles Book, 1970.

Dror, Tamar. A Green Parro: The Unearthed Memories of a Jewish Child Living under Nazi Occupation. Sydney: K. Altman, 1999.

Eber, Irene. The Choice: Poland 1939-1945. New York: Schocken, 2004.

Edvardson, Cordelia. Burned Child Seeks the Fire: A Memoir. 1984. Trans. Joel Agee. Boston: Beacon P, 1998.

Eichengreen, Lucille. From Ashes to Life: My Memories of the Holocaust. San Francisco: Mercury House, 1994.

Eilenberg, Anna. Breaking My Silence. New York: Shengold, 1985.

Eilenberg, Anna. Sisters in the Storm. New York: C.I.S., 1992.

Eliach, Yaffa. Hasidic Tales of the Holocaust. New York: Oxford UP, 1982. 
Louise O. Vasvári,

"Introduction to and Bibliography of Central European Women's Holocaust Life Writing in English" page 12 of 18

CLCWeb: Comparative Literature and Culture 11.1 (2009): <http://docs.lib.purdue.edu/clcweb/vol11/iss1/10>

Thematic Issue New Work in Holocaust Studies. Ed. Louise O. Vasvári and Steven Tötösy de Zepetnek

Elias, Ruth. Triumph of Hope: From Theresienstadt and Auschwitz to Israel. 1990. Trans. Margot Bettauer Dembo. New York: John Wiley and Sons, 1998.

Engelman, Matylda. The End of the Journey: An Autobiography. Los Angeles: Pinnacle Books, 1978.

Epstein, T. Scarlett. Swimming Upstream: A Jewish Refugee from Vienna. Portland: Vallentine Mitchell, 2005.

Esser, Barbara. Salo's Song. London: Vallentine Mitchell, 2004.

Farkas, Helen. Remember the Holocaust: A Memoir of Survival. Santa Barbara: Fithian P, 1995.

Farkas, Rose, and Ibi Winterman. Ruchele: Sixty Years from Szatmar to Los Angeles. Santa Barbara: Fithian P, 1998.

Feder Kurzband, Paula. The Feather-Bed Journey. Norton Grove: A. Whitman, 1995.

Feld, Marilla. I Chose to Live. New York: Manor Books, 1979.

Fénélon, Fania. The Musicians of Auschwitz. 1976. Trans. Judith Landry. London: Sphere, 1981.

Feniger, Saba. Short Stories, Long Memories. Melbourne: Vista Publications, 1999.

Ferderber-Salz, Berta. And the Sun Kept Shining. New York: Holocaust Library, 1980.

Fink, Ida. A Scrap of Time and Other Stories. 1987. Trans. Madeline Levine and Francine Prose. New York: Pantheon Books, 1987.

Fink, Ida. The Journey. 1990. Trans. Joanna Weschler and Francine Prose. New York: Farrar Straus Giroux, 1992.

Fink, Ida. Traces. 1996. Trans. Philip Boehm and Francine Prose. New York: Metropolitan Books, 1996.

Finkelstein, Genya. Genya. 1994. New York: GT Publishing, 1998.

Fischer, Erika. Aimée and Jaguar: A Love Story. Berlin 1943. 1994. Trans. Eana McCown. New York: Harper Collins, 1995.

Fischer, Marianne, with Gayle Roper. Time of Storm: The Harrowing True Story of a Jewish Christian Woman in Wartime Hungary. Chappaqua: Christian Herald Books, 1981.

Fischler-Martinho, Janina. Have You Seen My Little Sister? London: Vallentine Mitchell, 1998.

Fischman, Lala, and Steven Weingartner. Lala's Story. Evanston: Northwestern UP, 1997.

Fittko, Lisa. Escape through the Pyrenees. 1989. Trans. David Koblick. Evanston: Northwestern UP, 1991.

Fittko, Lisa. Solidarity and Treason: Resistance and Exile, 1933-1940.1992. Trans. Roslyn Theobald. Evanston: Northwestern UP, 1993.

Fluck, Toby K. Memories of My Life in a Polish Village. New York: Knopf, 1990.

Fox, Anne L. My Heart in a Suitcase. London: Vallentine Mitchell, 1996.

Frank, Anne. The Diary of a Young Girl. 1952. Trans. M. Mooyart-Doubleday. New York: Doubleday, 1995.

Fried, Hedi. Fragments of a Life: The Road to Auschwitz. London: Hale, 1990.

Friedman, Ina R. Flying against the Wind: The Story of a Young Woman Who Defied the Nazis. Brookline: Lodgepole P, 1984.

Friesova, Jana Renee. Fortress of My Youth: Memoir of a Terezin Survivor. Madison: U of Wisconsin P, 2002.

Fromer, Rebecca. The House By the Sea: A Portrait of the Holocaust in Greece. San Francisco: Mercury House, 1998.

Fuchs Chayen, Lea. From the Depth I Call. Southfield: Targum Press, 2000.

Furst, Lillian R., and Desider Furst. Home Is Somewhere Else: Autobiography in Two Voices. Albany: State U of New York P, 1994.

Furth, Valerie Jakober. Cabbages and Geraniums: Memories of the Holocaust. Boulder: Social Science Monographs, 1989.

Fuchs, Chayen Lea. From the Depths I Call. Southfield: Targum P, 2000.

Gabor, Georgia M. My Destiny: Survivor of the Holocaust. Arcadia: Amen Publications, 1981.

Games, Sonia. Escape into Darkness: The True Story of a Young Woman's Extraordinary Survival during World War II. New York: Shapolsky, 1991.

Garner Ramrath, Eleanor. Eleanor's Story: An American Girl in Hitler's Germany. Atlanta: Peach Tree, 1999.

Gefen, Aba. Hope in the Darkness: The Aba Gefen Diaries. New York: Holocaust Library, 1989.

Gissing, Vera. Pearls of Childhood. London: Robson, 1988.

Glas-Larsson, Margareta. I Want to Speak: The Tragedy and Banality of Survival in Terezin and Auschwitz. 1981. Trans. Lowell Bangerter. Riverside: Ariadne P, 1991.

Glas-Wiener, Sheva. Children of the Ghetto. 1974. Trans. Sheva Glas-Wiener and Shirley Young. Melbourne: Globe P, 1983.

Glasser, Ingeborg. Dance of the Panther: A Memoir. New York: Book Republic, 2006.

Gelissen Kornreich, Rena, and Heather Dunn MacAdam. Rena's Promise: A Story of Sisters in Auschwitz. Boston: Beacon P, 1995.

Gluck, Gemma LaGuardia. My Story. New York: David McKay, 1961.

Gluck La Guardia, Gemma. Fiorello's Sister: Gemma La Guardia Gluck's Story. Syracuse: Syracuse UP, 2007.

Goetzel-Leviathan, Sophie, The War Within. Ed. Rebecca Fomer. Trans. Geoffrey A.M. Block. Berkeley: Judah L. Magnes Museum, 1987.

Gold Glasberg, Ruth. Ruth's Journey: A Survivor's Memoir. Gainsville: UP of Florida, 1996.

Goldberg, Paulette. Just Think It Never Happened. Melbourne: Makor Jewish Community Library, 2002.

Goldberg, Zosia. Running through Fire: How I Survived the Holocaust. Washington: National Endowment for the Arts Heritage and Preservation Series, 2000.

Goldstein, Guta. There Will Be Tomorrow. Melbourne: Makor Jewish Community Center, 1999.

Gossman, Eva. Good Beyond Evil. Portland: Vallentine Mitchell, 2002. 
Louise O. Vasvári,

"Introduction to and Bibliography of Central European Women's Holocaust Life Writing in English" page 13 of 18

CLCWeb: Comparative Literature and Culture 11.1 (2009): <http://docs.lib.purdue.edu/clcweb/vol11/iss1/10>

Thematic Issue New Work in Holocaust Studies. Ed. Louise O. Vasvári and Steven Tötösy de Zepetnek

Gottlieb, Erika. Becoming My Mother's Daughter: A Story of Survival and Renewal. Waterloo: Wilfrid Laurier UP, 2008.

Gould, Lucy. Empty Corners: A Memoir. Melbourne: Makor Jewish Community Library, 2000.

Gould, Nadia. Hitler Made Me a Jew. Raleigh: Boston Books, 1996.

Graf, Malvina. The Krakow Ghetto and the Plaszow Camp Remembererd. Tallahassee: Florida State UP, 1989.

Greenfield, Hana. Fragments of Memory: From Kolin to Jerusalem. Jerusalem: Gefen, 1992.

Greenhut, Gitel. Mamuka. New York: CIS Publishers, 1991.

Grossman, Chaika. The Underground Army: Fighters of the Bialystok Ghetto. New York: Holocaust Library, 1987.

Grünbaum, Irene. Escape through the Balkans: The Autobiography of Irene Grünbaum. Lincoln: U of Nebraska P, 1996.

Gurdus Krugman, Luba. The Death Train. New York: Holocaust Library, 1978.

Haas, Gerda. This I Do Remember. Freeport: Cumberland P, 1982.

Hahn, Lilo. White Flags of Surrender: Jan. 1933 - Mar. 1945. Trans. Sibyl Milton. Washington: R.B. Luce, 1974.

Hahn-Beer, Edith, with Susan Dworkin. The Nazi Officer's Wife: How One Jewish Woman Survived the Holocaust. New York: William Morrow, 1999.

Hamermesh, Mira. The River of Angry Dogs: A Memoir. London: Pluto, 2004.

Harmannová, Margit. Those Who Want to Say Something to Future Generations Should Speak Out. Trans. Olga Kuthanová. Prague: Jewish Museum in Prague, 1994.

Hart, Kitty. I Am Alive. London: Abelard-Schuman, 1961.

Hart, Kitty. Return to Auschwitz: The Remarkable Story of a Girl Who Survived the Holocaust. New York: Atheneum, 1981.

Heilman, Anna. Never Far Away: The Auschwitz Chronicles of Anna Heilman. Ed. Sheldon Schwartz. Calgary: U of Calgary P, 2001.

Heller Gottesfeld, Fanya. Strange and Unexpected Love: A Teenage Girl's Holocaust Memoirs. Hoboken: Ktav, 1993.

Heller Gottesfeld, Fanya. Love in a World of Sorrow: A Teenage Girl's Holocaust Memoirs. Englewood: Devora Publishing, 2005.

Herbermann, Nanda. The Blessed Abyss: Inmate \#6582 in Ravensbrück Concentration Camp for Women. 1946. Trans. Hester Baer and Elizabeth Baer. Detroit: Wayne State UP, 2000.

Hersch, Gizelle, and Peggy Mann. Gizelle, Save the Children! New York: Everest House, 1980.

Herz, Gabriele. The Women's Camp in Moringen: A Memoir of Imprisonment in Germany, 1936-1937. New York: Berghahn, 2006.

Heyman, Eva. The Diary of Eva Heyman: Child of the Holocaust. 1947. Trans. Moshe M. Kohn. Jerusalem: Yad Vashem, 1988.

Hillesum, Etty. An Interrupted Life: The Diaries of Etty Hillesum, 1941-43. 1981. Grand Rapids: Eerdmans, 2002.

Hillesum, Etty. Letters from Westerbork. 1962. Trans. Arnold J. Pomerans. New York: Pantheon, 1986.

Hillman, Laura. I Will Plant You a Lilac Tree: A Memoir of a Schindler's List Survivor. New York: Athaneum Books for Young Readers, 2004.

Hirurg, Rivah. Bridge of Sorrow, Bridge of Hope. Berkeley: Judah L. Magnes Museum, 1984.

Hoffmann, Edith. Unshed Tears: A Novel . . . But Not a Fiction. Glasgow: Omnia Books, 2001.

Hoffman, Louise, and Shus Masel. Without Regret. Perth: U of Western Australia P, 1994.

Horak, Olga. Auschwitz to Australia: Survivor's Memoir. Melbourne: Kangoroo P, 2000.

Hyatt, Felicia B. Close Calls: The Autobiography of a Survivor. New York: Holocaust Library, 1991.

Iglinsky-Goodman, Leah. For Love of Life. London: Vallentine Mitchell, 2000.

Ilan-Onderwijzer, Jehudith. Their Image Will be Forever before my Eyes: Experiences of a Jewish Girl of the Dutch Diaspora during the Holocaust. New York: Gefen, 2003.

Isaacson Magyar, Judith. Seed of Sarah: Memoirs of a Survivor. Urbana: U of Illinois P, 1989.

Isaacman, Clara. Clara's Story. New York: Jewish Publications Society, 1984.

Jaegermann, Judith. My Childhood in the Holocaust. Jerusalem: Mazo, 2004.

Janowski, Niusia. A Life Apart. Victoria: Daniel Lewkovitz, 1993.

Kahn, Annette. Why My Father Died: A Daughter Confronts Her Family's Past at the Trial of Klaus Barbie. 1990. Trans. Anna Cancogni. New York: Summit, 1991.

Kalib Szachter, Goldie, with Sylvan Kalib and Ken Wachsberger. The Last Selection: A Child's Journey Through the Holocaust. Amherst: U of Massachusetts P, 1991.

Kalman, Judith. The County of Birches. New York: St. Martin's, 1998.

Kalman Naves, Elaine. Journey to Vaja: Reconstructing the World of a Hungarian Jewish Family. Montréal: McGillQueen's UP, 1996.

Kalman Naves, Elaine. Shoshanna's Story: A Mother, a Daughter, and the Shadows of History. Lincoln: U of Nebraska P, 2006.

Kaplan, Helen. I Never Left Janowska. New York: Holocaust Library, 1989.

Kaplan, Vivian Jeannette. The Green Bottles: The True Story of One Family's Journey from War-torn Austria to the Ghettos of Shanghai. New York: St. Martin's, 2004.

Karay, Felicja. Death Comes in Yellow: Skarzysko-Kamienna Slave Labor Camp. Trans. Sara Kitai. Amsterdam: Harwood Academic P, 1996.

Karas, Joza. Music in Terezin, 1941-1945. New York: Beaufort, 1985. 
Louise O. Vasvári,

"Introduction to and Bibliography of Central European Women's Holocaust Life Writing in English" page 14 of 18

CLCWeb: Comparative Literature and Culture 11.1 (2009): <http://docs.lib.purdue.edu/clcweb/vol11/iss1/10>

Thematic Issue New Work in Holocaust Studies. Ed. Louise O. Vasvári and Steven Tötösy de Zepetnek

Karmel, Ilona. Stephania. Boston: Houghton Mifflin, 1953.

Karmel, Ilona. An Estate of Memory. 1969. New York: Feminist P, 1989.

Kaszas, Susan. From Love to Triumph: Holocaust Diary, Auschwitz, Poland 1944. Dillich, Germany, 1945. Ed. June Marshall. Trans. Steven Kaszas. Ridgewood: AIL New Media, 2002.

Katin, Miriam. We Are on Our Own: A Memoir. Montréal: Drawn and Quarterly, 2006.

Katz, Etunia Bauer. Our Tomorrow Never Came. New York: Fordham UP, 2000.

Kazimirski, Ann. Witness to Horror. Montréal: Devonshire, 1993.

Kennedy, Eva. Appointment in Budapest: An Autobiographical Novel. New York: McGraw Hill, 1968.

Kern, Alice. Tapestry of Hope. Cathedral City: Limited Edition Books, 1988.

Kery, Iby. I Have Been Chosen. Melbourne: By the Author, 1985.

Kimmelman, Mira Rycke. Echoes from the Holocaust: A Memoir. Knoxville: U of Tennessee P, 1997.

Kimmelman, Mira Ryczke. Life Beyond the Holocaust: Memories and Realities. Knoxville: U of Tennessee P, 2005.

Kirschner, Ann. Sala's Gift: My Mother's Holocaust Story. New York: Free P, 2006.

Kisliuk, Ingrid. Unveiled Shadows: The Witness of a Child. A Memoir. 1988. Newton: Nanomir P, 1998.

Klarsfeld, Beata. Where They May Be! New York: The Vanguard P, 1972.

Klein, Aranka Ari. My Life Story. N.p.: By the Author, 2001.

Klein, Cecilia. Sentenced to Live: A Survivor's Memoir. New York: Holocaust Library, 1988.

Klein Weissman, Gerda. All But My Life. 1957. New York: Hill and Wang, 1995.

Klein Weissman, Gerda, and Kurt Weissman. Hours After: Letters of Love and Longing in the War's Aftermath. New York: St. Martin's P, 2000.

Klein, Rivka Leah. The Scent of Snowflowers: A Chronicle of Faith, Hope, and Survival in War-ravaged Budapest. New York: Feldheim, 1989.

Klüger, Ruth. Still Alive: A Holocaust Girlhood Remembered. New York: Feminist P, 2003.

Koehn, Ilse. Mischling, Second Degree: My Childhood in Nazi Germany. New York: Greenwillow, 1973.

Kofman, Sarah. Rue Ordener, rue Labat. Trans. Ann Smock. Lincoln: U of Nebraska P, 1990.

Kogosowski, Hanna. The Times of My Life. Melbourne: By the Author, 1991.

Kolmar, Gertrud. My Gaze is Turned Inward: Letters, 1939-1943. 1992. Trans. Brigitte M. Goldstein. Evanston: Northwestern UP, 2006.

Konopka, Gisela. Courage and Love. Edina: Buyess, 1988.

Kor Mozes, Eva, and Mary Wright. Echoes from Auschwitz: Dr. Mengele's Twins, the Story of Eva and Miriam Mozes. Terre Haute: Candles, 1995.

Kotlar, Helen. We Lived in a Grave. New York: Shengorn, 1980.

Kovaly Margolius, Heda. Under a Cruel Star: A Life in Prague, 1941-1968. 1973. Trans. Francis Epstein, Helen Epstein, and Heda Margolius Kovaly. New York: Holmes and Meier Publishers, 1997.

Knopfler, Clara. "I Am Still Here." My Mother's Voice. Bloomington: Author-House, 2007.

Korda, Teri. My Dear Andrea an Andris. Caulfield South: Makor Jewish Community Library, 2002.

Kovesi, Vera. Terror and Survival: A Family History. Montréal: Concordia University Chair in Canadian Jewish Studies, 2005.

Krakowski, Avra. Counterfeit Lives. New York: C.I.S. Publishers, 1995.

Krasno, Rena. Strangers Always: A Jewish Family in Wartime Shanghai. Berkeley: Pacific View P, 1992.

Krall, Hanna. Shielding the Flame. New York: Henry Holt, 1986.

Krinitz Nisenthal, Esther, and Bernice Steinhardt. Memories of Survival. New York: Hyperion, 2005.

Kühler-Silberman, Lena. My Hundred Children. 1963. New York: Dell Publishing, 1987.

Kuperhand, Miriam, and Saul Kuperhand. Shadows of Treblinka. Chicago: U of Illinois P, 1998.

Labson, Gabriella Auspitz. My Righteous Gentile: Lord Wedgewood and Other Memories. Jersey City: Ktav, 2004.

Ladanyi, Helena. Where Do You People Come From? Melbourne: Spectrum, 1988.

Langley-Danos, Eva M. Prison on Wheels: From Ravensbrück to Burgau. Einsiedeln: E. Langley-Damos and Daimon, 2000.

Langsus, Anna. The Whole Land Brimstone. Trans. Peter Wiles. New York: Pantheon, 1962.

Lasker-Wallfisch, Anita. Inherit the Truth, 1939-1945: The Documented Experiences of a Survivor of Auschwitz and Bergen-Belsen. London: Giles de la Mare, 1996.

Laskier, Rutka. Rutka's Notebook. Jerusalem: Yad Vashem, 2007.

Leizerson, Rachel. My Story. Melbourne: By the Author, 1988.

Lauer, Betty. Hiding in Plain Sight: The Incredible True Story of a German-Jewish Teenager's Struggle to Survive in Nazi-Occupied Poland. Hanover: Smith and Kraus, 2004.

Lebovitz, Shirley. The Enduring Spirit. Phoenix: Gildith, 1993.

Leitner, Isabella. Fragments of Isabella. New York: Thomas Y. Crowell, 1978.

Leitner, Isabella. Saving the Fragments: From Auschwitz to New York. New York: New American Library, 1985.

Leitner, Isabella. Isabella: From Auschwitz to Freedom. New York: Anchor Books, 1994.

Leitner, Isabella. The Big Lie: A True Story. New York: Scholastic, 1992.

Leizerson, Rachel. My Story. Melbourne: By the Author, 1990.

Lemelman, Gusta, and Martin Lemelman. Mendel's Daughter. New York: Free P, 2006.

Lengyel, Olga. I Survived Hitler's Ovens: A Woman Survivor's True Story of Auschwitz. 1946. Chicago: Academy Chicago P, 1995.

Lerner, Gerda. Farewell: A Political Autobiography. Philadelphia: Temple UP, 2002. 
Louise O. Vasvári,

"Introduction to and Bibliography of Central European Women's Holocaust Life Writing in English" page 15 of 18

CLCWeb: Comparative Literature and Culture 11.1 (2009): <http://docs.lib.purdue.edu/clcweb/vol11/iss1/10>

Thematic Issue New Work in Holocaust Studies. Ed. Louise O. Vasvári and Steven Tötösy de Zepetnek

Lerner, Lily Gluck, with Sandra Lee Stuart. The Silence. Secaucus: Lyle Stuart, 1981.

Levi, Trude. A Cat Called Adolf. London: Vallentine Mitchell, 1995.

Levi, Trude. Did You Ever Meet Hitler, Miss? A Holocaust Survivor Talks to Young People. London: Vallentine Mitchell, 2003.

Lévy-Hass, Hanna. Inside Belsen. 1978. Trans. Ronald Taylor. Brighton: Manchester P, 1982.

Lewinska, Pelagia. Twenty Months at Auschwitz. 1945. Trans. Albert Teichner. New York: Lyle Stuart, 1968.

Lewinson, Irene Alice. Half a Life: The First Forty Years. Melbourne: Vista Publications, 1996.

Lewis, Helen. A Time to Speak. Belfast: Blackstaff, 1992.

Lewitt, Maria. Come Spring. Melbourne: Scribe, 1980.

Liberman Celinga, Cila. A Child Survives Auschwitz. Jerusalem: Yad Vashem, 2002.

Lieblich, Ruthka. Ruthka: A Diary of War. Trans. and ed. Jehoshua Eibeshitz and Anna Eibeshitz. Brooklyn: Remember, 1993.

Liebmann, Henriette. Death Wore a Nazi Uniform. Melbourne: By the Author, 1988.

Liebster Arnold, Simone, with Sybil Milton. Facing the Lion: Memoirs of a Young Girl in Nazi Europe. New Orleans: Grammaton P, 2000.

Ligocka, Roma, and Iris von Finkenstein. The Girl in the Red Coat: A Memoir. Trans. Margot Bettauer Dembo. New York: St. Martin's, 2002.

Lingens-Reiner, Ella. Prisoners of Fear. London: Victor Gollanz, 1948.

Linn, Ruth. Escaping Auschwitz: A Culture of Forgetting. Ithaca: Cornell UP, 2004.

Lipstadt, Deborah. Beyond Belief. New York: The Free P, 1986.

Lipszyc Beer, Mordka. Memoirs of Mordka Beer Lipszyc. Melbourne: By the Author, 1998.

Lissing, Betty. God Cried at Auschwitz. Adelaide: LMN Systems, 2003.

Lobel, Anita. No Pretty Pictures: A Child of War. New York: Greenwillow Books, 1998.

Lozansky-Bogomolnaya, Rivka, and Susan Logan, eds. Wartime Experiences in Lithuania. Trans. Miriam Beckerman. London: Vallentine Mitchell, 2000.

Lubetkin, Zivia. In the Days of Destruction and Revolt. 1978. Trans. I. Tubbin. Tel Aviv: Hakibbutz, 1981.

Machlin Servi, Edda. Child of the Ghetto: Coming of Age in Fascist Italy 1926-1946. A Memoir. Croton-on-Hudson: Giro P, 1995.

Mack, John E., with Rita S. Rogers. The Alchemy of a Survivor: One Woman's Journey. Reading: Addison-Wesley, 1988.

Mahler, Margaret S. The Memoirs of Margaret S. Mahler. New York: Free P, 1988.

Mandelbaum, Rae. Echoes from the Past: The Rifka Normal Story. Melbourne: Makor Jewish Community Library, 1999.

Mardor, Munya. Haganah. New York: New American Library, 1957.

Marks, Eva. A Patchwork Life. Caulfield: Makor Jewish Community Library, 2003.

Maurel, Micheline. An Ordinary Camp. New York: Simon and Schuster, 1958.

McDonough Zeldis, Yona. The Doll with the Yellow Star. New York: Henry Holt, 2005.

Meed, Vladka. On Both Sides of the Wall. 1948. Trans. Benjamin Meed. Tel Aviv: Hakibbutz Hameuchad, 1973.

Meissner, Margit. Margit's Story: An Autobiography. Rockville: Schreibner, 2003.

Melammed Levine, Renee. "The Memoirs of a Partisan from Salonika." Autobiography and Memoir. Special Issue Nashun: A Journal of Jewish Women's Studies and Gender Issues 7 (2004): 151-73.

Mermelstein Feurman, Joan. Out from the Ashes: My Life Story. Memoirs of a Holocaust Survivor. 1984. Cincinnati: Northern Hill Synagogue Congregation B'nai Avrahim, 2005.

Michelson, Frida, with Wolf Goodman. I Survived Rumbuli. 1973. New York: Holocaust Library, 1979.

Miklos, Sophie Weisz. Paper Gauze Ballerina: Memoir of a Holocaust Survivor. Chapel Hill: By the Author, 1998.

Miller, Joy. Love Carried Me Home: Women Surviving Auschwitz. Deerfield Beach: Simcha P, 2000.

Millu, Liana. Smoke over Birkenau. 1986. Trans. Lynne Sharon Schwarz. Evanston: Northwestern UP, 1998.

Morhange-Bégué, Claude. Chamberet: Recollections from an Ordinary Childhood. Trans. Austryn Wainhouse. Evanston: Northwestern UP, 2000.

Moskin, Marietta. I am Rosemarie. New York: Dell, 1972.

Mozes, Terez. Staying Human through the Holocaust. Calgary: U of Calgary P, 2005.

Muchman, Beatrice. Never to Be Forgotten: A Young Girl's Holocaust Memoir. Hoboken: Ktav, 1997.

Müller-Madej, Stella. The Girl from Schindler's List. 1991. Trans. William R. Bland. London: Polish Cultural Foundation, 1997.

Nadel, Lita. From Two Hells: An Autobiography. Sydney: By the Author, 1995.

Nagler, Eva. Massacre on the Baltic. Melbourne: By the Author, 1995.

Nelken, Halina. And Yet I am Here. 1986. Trans. Halina Nelken and Alicia Nitecki. Amherst: U of Massachusetts P, 1999.

Nemirovsky, Irène. Suite française. 2004. Trans. Sandra Smith. New York: Knopf, 2006.

Neray Bindefeld, Ruth. Death by Design. Toronto: Childe Thursday, 1992.

Newman Sternberg, Judith. In the Hell of Auschwitz: Wartime Memoirs. New York: Exposition, 1963.

Nomberg-Przytyk, Sara. Auschwitz: True Tales from a Grotesque Land. Chapel Hill: U of North Carolina P, 1985.

Nomberg-Przytyk, Sara. Esther's First Born. Austin: Amor Fati, 1990.

Novac, Ana. The Beautiful Days of My Life: My Six Months in Auschwitz and Plaszkow. 1967. Trans. George L. Newman. New York: Henry Holt, 1997. 
Louise O. Vasvári,

"Introduction to and Bibliography of Central European Women's Holocaust Life Writing in English" page 16 of 18

CLCWeb: Comparative Literature and Culture 11.1 (2009): <http://docs.lib.purdue.edu/clcweb/vol11/iss1/10>

Thematic Issue New Work in Holocaust Studies. Ed. Louise O. Vasvári and Steven Tötösy de Zepetnek

Novack Mandel, Judith. The Lilac Bush. New York: Shengold Publishers, 1989.

Novitch, Miriam. Sobibor: Martyrdom and Revolt. New York: Schocken, 1980.

Oberski, Jona. Childhood. 1978. Trans. Ralph Manheim. New York: Doubleday, 1983.

Olensky, Luba. A Life Reclaimed: A Child among the Partisans. Melbourne: Makor Jewish Community Library, 2006. Opolyke Gut, Irene. In My Hands: Memories of a Holocaust Rescuer. New York: Knopf, 1999.

Ornstein, Anna. My Mother's Eyes: Holocaust Memories of a Young Girl. Cincinnati: Emmis Books, 2004.

Pardo Asser, Rozina. 548 Days with Another Name: Salonika 1943. Memories of the War. 1999. New York: Bloch Publishers, 2005.

Pawel, Ursula. My Child is Back! London: Vallentine Mitchell, 2000.

Pawlowicz, Sala, and Kevin Klose. I Will Survive. London: Muller, 1962.

Penney, Frances. I Was There. New York: Shengold, 1988.

Perl, Gisella. I Was a Doctor in Auschwitz. 1948. Manchester: Ayer Company Publishing, 1998.

Perl, Lila, and Marion Blumenthal Lazar. Four Perfect Pebbles: A Holocaust Story. New York: Greenwillow, 1996.

Perloff, Marjorie. The Vienna Paradox: A Memoir. New York: New Directions Books, 2004.

Polcz, Alaine. One Woman in the War: Hungary, 1944-45. 1991. Trans. Albert Tezla. Budapest: Central European UP, 2002.

Pollatscheck, Henrietta, and Renata Polt. A Thousand Kisses: A Grandmother's Holocaust Letters. Tuscaloosa: U of Alabama P, 1999.

Poltawska, Wanda. And I am Afraid of My Dreams. London: Hodder and Stoughton, 1987.

Prager, Rita. Chai to Life. The Sum of my Roots. Sydney: Sydney Jewish Museum, 2005.

Quittner, Eva. Pebbles of Remembrance. Balmain: Kerr, 1993.

Raab, Elisabeth M. And Peace Never Came. Waterloo: Wilfrid Laurier UP, 1997.

Rabinovici, Schoschana. Thanks to My Mother. 1991. Trans. James Skofield. New York: Dial Books, 1998.

Rack, Ruth. Book of Ruth: Memoirs of a Child Survivor. Sydney: Southern Highlands, 2002.

Rado, Greta. Greta's Story. Adelaide: Ginninderra P, 2008.

Randall-Silbermann, Marga. How Beautiful We Once Were: A Remembrance of the Holocaust and Beyond. Pittsburgh: Cathedral, 1998.

Reisman, Kathy. More than Nine Lives. Melbourne: Makor Jewish Community Library, 2002.

Reiss, Johanna. The Upstairs Room. New York: Crowell, 1973

Reiss, Johanna. The Journey Back. New York: Crowell, 1976.

Reisman, Kathy. More Than Nine Lives. Melbourne: Makor Jewish Community Library, 2002.

Rexin Evans, Cecelia, Nancy Rexin Evans, and Mark Shaw. Testament to Courage: The Concentration Camp Diary 1940-1945 of a Courageous German Woman Who Risked Her Life to Save Others. Carmel: Guild P of Indiana, 1998.

Richman, Sophia. A Wolf in the Attic: The Legacy of a Hidden Child. New York: Haworth P, 2002.

Robinson, Halina. A Cork on the Waves. Sydney: Sydney Jewish Museum, 2005.

Roden, Eva, and Ruda Roden. Lives on Borrowed Time. New York: Carleton P, 1984.

Roi, Emilyah. A Different Story: About a Danish Girl in World War Two. 1980. Trans. Miriam Arad. Jerualem: Yad Vashem, 1990.

Rose, Leesha. The Tulips Are Red: The Story of a Jewish Girl in the Dutch Resistance during World War II. Jerusalem: Yad Vashem, 1978.

Rosen, Donia. The Forest, My Friend. New York: Bergen-Belsen Memorial P, 1971.

Rosen, Sara. My Lost World. London: Vallentine Mitchell, 1993.

Rosenberg, Blanca. To Tell at Last: Survival under False Identity, 1941-45. Urbana: U of Illinois P, 1993.

Rosenberg Jedwab, Lena. Girl with Two Landscapes: The Wartime Diary of Lena Jedwab, 1941-1945. Trans. Solon Bienfeld. New York: Holmes and Meier, 2002.

Rosenbloom, Fela. Miracles Do Happen: Memoirs of Fela Rosenbloom. Melbourne: Scribe, 1994.

Roth, Milena. Lifesaving Letters: A Child's Flight from the Holocaust. Seattle: U of Washington P, 2004.

Roth-Hano, Renee. Touch Wood: A Girlhood in Occupied France. New York: Four Winds P, 1988.

Roubícková Mándlová, Eva. We're Alive and Life Goes On: A Theresienstadt Diary. Trans. Zaia Alexander. New York: Henry Holt, 1998.

Rubinstein, Donna. I am the Only Survivor of Krasnostav. New York: Shengold, 1982.

Rubenstin, Erna F. The Survivor in Us All: A Memoir of the Holocausst. Hamden: Arch on Books, 1983.

Rudolph [Rudolf], Joanne Werner. Witness: Voices from the Holocaust. New York: The Free P, 2000.

Russ, Irene. The Rest You Know. A Mother's Story of Survival. Austin: Idea University P, 2001.

Rybak, Rywka. Ryska Rybak: A Survivor of the Holocaust. Cleveland: Tricycle P, 1993.

Salomon, Charlotte. Life or Theater: An Autobiographical Play. Trans. Leila Vennewitz. New York: Viking, 1981.

Sandy, Kitty. Stormy Weather: A Life's Journey from Budapest to Melbourne. Melbourne: Makor Jewish Community Library, 2006.

Sasoon, Agnes. Agnes: How my Spirit Survived. Edgeware: Lawrence Cohen, 1983.

Schimmel, Betty, with Joyce Gabriel. To See You Again: A True Story of Love in a Time of War. New York: Dutton, 1999.

Schloss, Eva, with Evelyn Julia Kent. Eva's Story: A Survivor's Tale by the Step-Sister of Ann Frank. London: W.H. Allen, 1988.

Schriber, Vera. The Porcelain Doll. Caulfield South: Makor Jewish Community Library, 2000. 
Louise O. Vasvári,

"Introduction to and Bibliography of Central European Women's Holocaust Life Writing in English" page 17 of 18

CLCWeb: Comparative Literature and Culture 11.1 (2009): <http://docs.lib.purdue.edu/clcweb/vol11/iss1/10>

Thematic Issue New Work in Holocaust Studies. Ed. Louise O. Vasvári and Steven Tötösy de Zepetnek

Schulman, Faye, and Sarah Silberstein Swartz. A Partisan's Memoir: Woman of the Holocaust. Toronto: Second Story P, 1995.

Schwarz, Renée Fodor. Renée. New York: Shengold, 1991.

Schwertfeger, Ruth. Women of Theresienstadt: Voices from a Concentration Camp. New York: Berg, 1988.

Seloules, Edith. Surviving the Nazis, Exile, and Siberia. London: Vallentin and Mitchell, 2000.

Selver-Urbach, Sara. Through the Window of My Home.1964. Jerusalem: Yad Vashem, 1986.

Segal, Lore. Other People's Houses. New York: St. Martin's, 1988.

Sender Minsky, Ruth. The Cage. New York: MacMillan, 1986.

Sender Minsky, Ruth. The Holocaust Lady. New York: MacMillan, 2002.

Senesh, Hannah. Her Life and Diary: The First Complete Edition. Woodstock: Jewish Lights Publishing, 2004.

Sherman, Judith. A Survivor's Tale in Prose and Poetry. Albuquerque: U of New Mexico P, 2005.

Siegal, Aranka. Upon the Head of a Goat: A Childhood in Hungary, 1939-1944. London: Dent, 1982.

Siegal, Aranka. Grace in the Wilderness: After the Liberation, 1945-1948. New York: Farrar, Straus, Grace, 1985.

Siegal, Aranka. Memories of Babi: Stories. New York: Farrar, Straus \& Giroux, 2008.

Silton, Faye. Of Heroes, Hooks, and Heirlooms. New York: Jewish Publication Society, 1997.

Snap, Le'ah. Hatikvah in Auschwitz. Haifa: Lea Schnapp, 1993.

Sonnino, Piera. This Happened: An Italian Family in Auschwitz. 2004. Trans. Ann Goldstein. New York: Palgrave, 2006.

Soumerai Nussbaum, Eva, and Carol D. Schultz. A Voice from the Holocaust. New York: Greenwood, 2003.

Spencer, Hanna. Hanna's Diary, 1938-1941: Czechoslovakia to Canada. Montréal: McGill-Queen's UP, 2001.

Spies, Gerty. My Years in Theresienstadt: How One Woman Survived the Holocaust. 1984. Trans. Jutta R. Tragnitz. New York: Holocaust Library, 1990.

Sprada, Regina, and Geoff Prigge. Laugh to Survive. Melbourne: Geoff Prigge, 1993.

Sput-Stern, Anna. On the Other Side of the River. Melbourne: Aussie Publications, 1999.

Stadler, Aranka. Mosaics of a Nightmare. London: Kall-Kwik Printing, 1995.

Starkiewicz, Helena. Blades of Grass Between the Stones. Melbourne: By the Author, 1998.

Steel, Helen Rose. T.B. versus Nazi. Melbourne: By the Author, 1987.

Steigman-Carmelly, Felicia. Shattered! Fifty Years of Silence: History and Voices of the Tragedy in Romania and Transnistria. Scarborough: Abbeyfield, 1997.

Steinberg, Irene. My Childhood in Hungary. Trans. Miriam Renkel. New York: Vantage P, 1992.

Strauss, Lotte. Over the Green Hill: A German Jewish Memoir, 1913-1943. New York: Fordham UP, 1999.

Suleiman Rubin, Susan. Budapest Diary: In Search of the Mother Book. Lincoln: U of Nebraska P, 1996.

Sutin, Jack, and Rochelle Jack. Jack and Rochelle: A Holocaust Story of Love and Resistance. St. Paul: Graywolf, 1999.

Syrkin, Marie. Blessed is the Match. 1947. Philadelphia: Jewish Publication Society, 1977.

Szereszewska, Helen, and Anna Marianska. Memoirs from Occupied Warsaw, 1940-1945. London: Vallentin Mitchell, 1997.

Szmaglewska, Seweryna. 1945. Smoke over Birkenau. Trans. Jadwiga Rynas. New York: Henry Holt, 1947.

Blady-Szwajger, Adina. I Remember Nothing More: The Warsaw Children's Hospital and the Jewish Resistance. Trans. Tasja Darowska and Danusia Stok. New York: Simon and Schuster, 1990.

Tec, Nechama. Dry Tears: The Story of a Lost Childhood. 1982. Oxford: Oxford UP, 1984.

Tedeschi Brunelli, Giuliana. There is a Place on Earth: A Woman in Birkenau. 1946. Trans. Tim Parks. London: Lime Tree $\mathrm{P}, 1993$.

Ten Boon, Corrie. A Prisoner and Yet. 1946. London: Christian Literature Crusade, 1954.

Ten Boon, Corrie, with Elizabeth Sherrill. The Hiding Place. New York: Guidepost Associates, 1971.

Thein, Magda. The Emigrant Element: A Wandering Jew's Journey from Budapest to New York. New York: By the Author, 2000.

Tichauer, Eva. I was Number 29832 at Auschwitz. London: Vallentine Mitchell, 2001.

Tillion, Germaine. Ravensbrück: An Eyewitness Account of a Women's Concentration Camp. 1973. Trans. Gerard Satter White. New York: Doubleday, 1975.

Toll, Nelly S. Behind the Secret Window: A Memoir of a Hidden Childhood during World War Two. New York: Dial, 1993.

Trahan Welt, Elizabeth. Walking with Ghosts: A Jewish Childhood in Wartime Vienna. New York: Peter Lang, 1998.

Turgel, Gina, with Veronica Groocock. I Light a Candle. London: Vallentin Mitchell, 1995.

Vaisman, Sima. A Jewish Doctor in Auschwitz: The Testimony of Sima Vaisman. 1945. Trans. Charlotte Mandel. Hoboken: Melville House, 2005.

Varga, Susan. Heddy and Me. Ringwood: Penguin, 1994.

Varon, Laura. The Juderia: A Holocaust Survivor's Tribute to the Jewish Community of Rhodes. Westport: Praeger, 1999.

Vas, Magda. A Life Lost and Found. N.p.: The Author, 2001.

Vegh, Claudine. I Didn't Say Good-by. New York: E.P. Dutton, 1979.

Velmans[-Van Hessen], Edith. Edith's Story. Harmondsworth: Penguin, 1998.

Verdoner-Sluizer, Hilde. Signs of Life: The Letters of Hilde Verdoner-Sluizer from Nazi Transit Camp Westerbork, 1942-44. Washington: Acropolis Books, 1990.

Vinocur, Ana. A Book Without a Title. 1972. Trans. Valentine Isaac and Ricardo Iglesia. New York: Vintage, 1976. 
Louise O. Vasvári,

"Introduction to and Bibliography of Central European Women's Holocaust Life Writing in English" page 18 of 18

CLCWeb: Comparative Literature and Culture 11.1 (2009): <http://docs.lib.purdue.edu/clcweb/vol11/iss1/10>

Thematic Issue New Work in Holocaust Studies. Ed. Louise O. Vasvári and Steven Tötösy de Zepetnek

Vrbova, Gerta. Trust and Deceit: A Tale of Survival in Slovakia and Hungary, 1939-45. London: Vallentin Mitchell, 2005.

Walker, Fay, and Leo Rosen. Hidden: A Sister and Brother in Nazi Poland. Madison: U of Wisconsin P, 2002.

Wallach, Jafa. Bitter Freedom: Memoirs of a Holocaust Survivor. Schuykill Haven: Hermitage, 2006.

Warren, Helen. The Buried are Screaming. New York: Beechhurst P, 1948.

Waterford, Helen H. Commitment to the Dead: One Woman's Journey toward Understanding. Frederic: Renaissance House, 1987.

Weinstein Scheps, Frida. A Hidden Childhood: A Jewish Girl's Sanctuary in a French Convent, 1942-1945. 1983. Trans. Barbara Loeb Kennedy. New York: Farrar, Straus and Giroux, 1985.

Weiss, Celia. Where Once I Walked. Np.: By the Author, 1992.

Weiss, Lotte. My Two Lives. Sydney: Jewish Museum, 2003.

Weiss, Reska. Journey through Hell. London: Vallentine Mitchell, 1961.

Weitz Schreiber, Sonia. I Promised I Would Tell. Brookline: Facing History and Ourselves, 1993.

Westheimer, Ruth, with Ben Yagoda. All in a Lifetime. New York: Warner Books, 1987.

White, Irene Zarina. Fire Burns: World War II Diaries. Philadelphia: Xlibris, 2006.

White Rosh, Naomi. From Darkness to Light: Surviving the Holocaust. Melbourne: Collins Dove, 1988.

Whiteley Mehler, Suzanne. Appel is Forever: A Child's Memoir. Detroit: Wayne State UP, 1999.

Williams, Laura E. Behind the Bedroom Wall. Milwaukee: Milkweed, 1996.

Winecki, Christine. From Stanislasow to Australia. London: Vallentine Mitchell, 2005.

Winter, Miriam. Trains: A Memoir of a Hidden Childhood during and after World War II. Jackson: Kelton P, 1997.

Widawski, Celina. The Sun Will Shine Tomorrow. Melbourne: By the Author, 1993.

Wiseman, Eva. Kanada. Toronto: Tundra Books, 2006.

Wiseman, Eva. My Canary Yellow Star. Toronto: Tundra Books, 2001.

Wolf, Charlotte. Hindsight: An Autobiography. London: Quarter Books, 1980.

Wolf, Sarah. Ingrained Memories. New York: Vantage P, 2000.

Zamoyska-Panek, Christine, and Fred Benton Holmberg. Have You Forgotten? A Memoir of Poland 1939-1945. New York: Doubleday, 1989.

Zar, Rose. In the Mouth of the Wolf. Philadelphia: Jewish Publication Society of America, 1983.

Zassenhaus, Hiltgunt. Walls: Resisting the Third Reich: One Woman's Story. Boston: Beacon P, 1974.

Zilversmit, Kitty. Yours Always: A Holocaust Love Story. Bethesda: CDL P, 1995.

Zimeung, Sabina S. Hiding in Plain Sight. St. Cloud: North Star P, 2001.

Zuker-Bujanowska, Liliana. Liliana's Journal: Warsaw, 1939-1945. New York: Dial P, 1980.

Zyskind, Sara. Stolen Years. 1978. Trans. Margarit Inbar. Minneapolis: Lerner, 1981.

Zyskind, Sara. Struggle. 1977. Minneapolis: Lerner Publications, 1989.

Zywulska, Krystyna [Zosia Landau]. I Came Back. 1946. Trans. Krystyna Cenkalska. London: Dobson, 1951.

Note: Funding for the completion of the above publication by the National Sun Yat-sen University Center for the Humanities and Social Sciences is gratefully acknowledged.

Author's profile: Louise O. Vasvári taught at the State University of New York Stony Brook where she is professor emerita and now teaches at New York University. Vasvári's areas of scholarship include medieval literature, sociolinguistics, translation theory, and Holocaust Studies, all informed by gender theory. Her recent single-authored books include The Heterotextual Body of the "Mora Morilla" (1999) and the edited volumes Companion to the "Libro de Buen Amor" (with Louise Haywood, 2004), Imre Kertész and Holocaust Literature (with Steven Tötösy de Zepetnek), Comparative Central European Holocaust Studies (with Steven Tötösy de Zepetnek), and Comparative Hungarian Cultural Studies (with Steven Tötösy de Zepetnek). E-mail: <louise.vasvari@sunysb.edu> 